\title{
Research of English Teachers' Teaching Motivation in Independent College
}

\author{
Xiujuan Li \\ Wuchang Shouyi University, Wuhan, 430064, China; \\ Xiangjun Xu \\ Wuhan Mechanical College, Wuhan, 430075, China
}

\author{
Yu Mei \\ Wuhan Mechanical College, Wuhan, 430075, China \\ Zhongmin Liu* \\ Wuhan Mechanical College, Wuhan, 430075, China \\ * Corresponding author. E-mail: 1137645276@qq.com
}

\begin{abstract}
The empirical study surveys the teaching motivation of 90 college English teachers from 3 different independent colleges. The results show that the Independent College English teachers' internal teaching motivation is stronger than external teaching motivation and the two have a significant difference. the first important influential factors are students' cooperation, salary, and workload, chances for advanced training, family and physical situation. The second important influential factors are cohesion of department, assessment from colleagues and students, the instability of the independent colleges, and the teaching equipments and auditing from the leaders and colleagues. Scientific research has no effect on teaching motivation in the independent colleges which is different from other public universities in China.
\end{abstract}

Key words- English teachers from independent colleges; teaching motivation; influential factors.

\section{INTRODUCTION}

Teaching motivation is the inner power driving teachers' to complete teaching activities positively, which activates, maintains and regulates teachers' teaching behaviors and has become an important factor influencing students' performance (Johnson, 2000:2). However, the studies of teachers' motivation, especially of foreign language teachers' motivation, are limited.

In 1991, Pennington researched the degree of working satisfaction of 100 language teachers in Teachers of English to Speakers of Other Language
(TESOL). At the same time, she did the same research in some Hong Kong middle school. She found that the teachers' were with declining devotion, high pressure, low salary, and low self-determination.

The domestic study of teaching motivation is only in the beginning phase. Lu Yongli (2012) concluded teacher's motivational theories and studies at abroad and implied a new perspective for the research in these areas. But there is only one empirical study of college English teachers' teaching motivation from Tang Wenli (2011). She found that the main influential factors of teaching motivation included students' participation, cohesion of department and scientific research pressure. Wang Yong (2014) researched the teaching motivation of professional interpreting in Chinese colleges. He found that their external motivation was stronger than internal motivation and there were no significant differences between them. These two researches above just mentioned the teachers in public Universities in China. Their teaching motivation and influential factors have specific characteristics. But there have no research about influential factors of teaching motivation of college English teachers in Independent College which is the new phenomenon of higher education in China. This essay intends to investigate Chinese Independent College English teachers' teaching motivation and influential factors.

\section{Methodology}

2.1 Research questions

The survey intends to study the current situation of 
Independent College English teachers' teaching motivation and the influential factors based on the following three questions:1) what is the principal teaching motivation of Independence College English teachers? 2) are there any significant difference between teachers' internal and external teaching motivation? 3) what are the major influential factors of Independent College English teachers' teaching motivation?

\subsection{Subjects and instrument}

Ninety English teachers from three Independent Colleges in Wuhan are involved in this study. The majority of the teachers who participate in the survey are female with the proportion of $90.1 \%$. $25.5 \%$ of teachers are under the age of thirty and nearly $70 \%$ of teachers are in the age of thirty to thirty-nine. Only $4.5 \%$ of the teachers are above forty. The imbalanced proportion of gender and age shows the specific characteristic of Independent College in China.

The questionnaire of Independent College English teachers' teaching motivation, which was designed by referring to relevant questionnaires from Tang Wenli and Wang Yong and considering the specific characteristics of Independent College teachers, includes the current teaching motivation situation and its influential factors. The first part contains the current situation of Independent College English teachers' teaching motivation which includes internal motivation (ten items), external motivation (nine items) and teachers' efforts (ten items). The average score of each item is calculated. The higher is the score, the stronger is the subjects' teaching motivation.

The second part investigates influential factors of Independent College English teachers' teaching motivation (fifteen items). The questionnaire offers a five-points scoring method, which means five choices for each item, ranging from "strongly disagree", "disagree", "uncertain", "agree", "strongly agree", a corresponding score is allocated for each choice: five scores for choosing five, four for choosing four, three for choosing four, two for two scores, one for one score.

In this study, the interview intends to investigate teachers' teaching situation and influential factors in Independent College. The interview mainly involves teachers' views on teaching career and teaching motivation.

\section{Results and Discussion}

The study uses SPSS to calculate the average score and the percentage and to test the difference between internal and external motivation with Paired-Samples $\mathrm{T}$ Test. And the coefficient of reliability of the whole questionnaire is .854 . The average scores of internal motivation and external motivation are 4.0078 and 3.2025 respectively. According to the figure above, internal motivation of Independent College English teachers is stronger than external motivation and the two have a significant difference $(\mathrm{p}=.000)$

\subsection{Analysis of internal motivation}

The scores of all the items about teachers' internal motivation are above 3 points, indicating that internal teaching motivation is a little strong on the whole.

The average scores of "I am interested in college English teaching", "I think teaching English is suitable for me", and "I love to stay with my students" are above 4 points. It indicates that most of Independent College English teachers choose to teach because they love this job, love to communicate with students and think they have responsibility and are qualified for the job. These three items are the important constituents of internal teaching motivation which can influence the teaching effects greatly. In the interview, most of teachers address that responsibility as a teacher and teaching interest urge them to make effort to teach. The average score of "college English teaching is full of challenge" is 4.04. It indicates that most of teachers think that college English teaching in Independent College is not easy to fulfill and becomes more and more challengeable. Students have a variety of needs which are difficult to satisfy in the present teaching pattern. The average score of "I really care about teaching effects" is 4.53 . Nearly $99 \%$ of teachers point out that they have serious attitude towards teaching and hope that students can benefit from the 
efforts they made.

\subsection{Analysis of external motivation}

The average scores of "to satisfy students' learning needs", "to be respected by students" and "to achieve handsome prize" are above 3.5 which are the important constituents of external teaching motivation and play a significant role in external teaching motivation. And the average scores of "to get high score in the teaching evaluation", "to get colleagues' approval" and "to promote professional titles" are above 3 points which indicates that these three items play a moderate role in external teaching motivation.

\subsection{Teachers' involvement}

Most of the items about teachers' involvement are above 4 points which indicates that teachers have made active efforts in order to do the job well. "Teachers always refer to the dictionaries or reference books", "even teachers who are at the age of fifties always read journals or e-books to accumulate teaching materials", which is different from the results of the survey of public universities' teachers from Tang Wenli. All the teachers involve in the process of designing teaching activities and cooperation with students, checking assignments and exploring new teaching methods, no declining with the increasing ages. For the item "I don't prepare before class if I have taught few times", nearly all the teachers choose "strongly disagree" or "disagree" which also indicates teachers' efforts on teaching preparation are consistent. Only two teachers with the age above fifty choose "agree", which indicates that proficient teachers have sufficient teaching experience and are familiar with teaching materials and then spend much more time and energy on modern teaching methods and teaching theories.The average score of "I always make PowerPoint to attract students in the class" is below 4 points especially for the subjects above forties, which indicates teachers' involvement in making PowerPoint is decreasing with the age increasing.

3.4 Influential factors of teaching motivation

The survey shows that the first important influential factors of teaching motivation include positive cooperation from students, salary, workload, training opportunities at home and abroad, health situation and family. In the item "students' cooperation influences my teaching motivation", $76.7 \%$ of teachers point out that students' positive learning attitude and cooperation can promote teachers' teaching enthusiasm. In the item "salary influences my teaching motivation", 73.3\% of teachers choose " $4=$ agree", which indicates salary level in Independent College is below teachers' expectation and becomes an important influential factor of teaching motivation. In the item "workload influences my teaching motivation", $46.7 \%$ of teachers choose "4=agree", which indicates that English teachers in Independent College are with heavy workload which influences teachers' enthusiasm and teaching effects to a certain extent. In the item "training opportunities at home and abroad", $48.8 \%$ of teachers choose "4=agree", which indicates teachers in Independent College eagerly attend training conferences and communicate with experts at home and abroad in order to improve teaching level. Most of English teachers in Independent College have no learning experiences at abroad and there are few opportunities for them to meet experts who can instruct and train them. In the item "health situation and family influence my teaching motivation", $42.2 \%$ and $23.3 \%$ of teachers choose " $4=$ agree" and " $5=$ strongly agree", which is caused by the special teaching constituents in Independent College. $70 \%$ of English teachers are female who are at the age of getting married or raising little children. They spend a large amount of energy on family and then have to decrease the devotion to teaching. They must be prepared for emergencies from teaching and family at any time and have no time to learn professional knowledge.

The second important influential factors of teaching motivation include cohesion of department, the evaluation from students and colleagues, instability of Independent Colleges, teaching equipments and sudden supervision or arrival of leaders with the average scores of 3 to 3.5 points. The factor of instability of Independent College causes teachers' deepest anxiety. 
They worry about unemployment if Colleges can not recruit students.

The item "scientific research can influence my teaching motivation" has the lowest average score which is only 2.8 points. $26.7 \%$ and $36.7 \%$ of teachers choose "2=disagree" and " $3=$ uncertain" which indicates the immature situation of scientific research in Independent Colleges. Teachers lack time and energy to focus on scientific research because of heavy workload and especially lack of the instructors of scientific research and environment to do the research. The scientific research of English teaching has been a big problem which greatly influences the promotion of professional titles for Independent College English teachers.

\section{Conclusion}

The survey researches the situation of teaching motivation and influential factors of teaching motivation of English teachers in Independent College. The results of the survey show: 1) the internal teaching motivation of Independent College English teachers is stronger than external teaching motivation and the two have a significant difference. 2) the first important influential factors of teaching motivation include positive cooperation from students, salary, workload, training opportunities at home and abroad, health situation and family. The second important influential factors of teaching motivation include cohesion of department, the evaluation from students and colleagues, instability of
Independent Colleges, teaching equipments and sudden supervision or arrival of leaders. Scientific research has no influences on teaching motivation which is different from public universities in China.

\section{References}

[1] Dornye, Z. Conceptualizing motivation in foreign language learning [J] . Language Learning, 1990(40): 46-78.

[2] Dornye, Z. Teaching and Researching Motivation[M]. Beijing: Foreign Language Teaching and Research Press, 2001.

[3] Gardner, R. C. Social Psychology and Language Learning: The Role of Attitudes and Motivation [M] . London, UK: Edwand Arnold, 1985:39-61.

[4] Gardner, R. C. Integrative motivation: Past, present and future $[\mathrm{J} / \mathrm{OL}]$. Accessed from http: publish. uw 0. $\mathrm{ca} /$ gardner/.2001:3-6.

[5] Johnson, C. R. (2000). Factors influencing motivation and demotivation in Mexican EFL teachers [J]. ERIC_NO: ED459605.

[6] Pennington, M. C. Work Satisfaction, Motivation, and Commitment in Teaching English as Second Language [M] . Unpublished manuscript, University of Luton, UK, 1995. (ERIC Document Reproduction Service No. Ed 404850).

[7] Lu Yongli, Luan Zitong, Qiao Miao. Research of Teaching Motivation Theories abroad [ J ] . Comparative Education Research , 2012 (6): 67-71.

[8] Tang Wenli. The Research of College English Teachers' Teaching motivation $[\mathrm{J}]$. Current Foreign Language Research, 2011 (4): 29-33.

[9] Wang Yong. The empirical study of College Interpreting teachers' teaching motivation in China[J]. Foreign Language Teaching, 2014 (2), 108-112. 